\title{
Zonula occludens-1 associated nucleic acid binding protein plays an invasion- promoting role in bladder cancer
}

\author{
X. XU' $\mathrm{X}^{1}, \mathrm{~K} . \mathrm{YOU}^{2}, \mathrm{~B} \cdot \mathrm{WU}^{1, *}$ \\ ${ }^{1}$ Department of Urology, Shengjing Hospital of China Medical University, Shenyang, Liaoning, China; ${ }^{2}$ Department of Neonatology, Shengjing \\ Hospital of China Medical University, Shenyang, Liaoning, China \\ ${ }^{*}$ Correspondence: wubin6698@sohu.com
}

Received July 25, 2018 / Accepted November 21, 2018

\begin{abstract}
Cancer cell invasion is an important characteristic of malignant tumors. Cancer cells overcome the constraints of tight junctions (TJ) to invade other tissues, but less is known about the regulating role of tight junctions in bladder cancer (BC) invasion. In order to identify the invasion-regulating function of tight junction component, we investigated the oncogenic features of zonula occludens- 1 associated nucleic acid binding protein (ZONAB), a TJ protein that is usually highly expressed in solid cancers. Expression of ZONAB was found to be up-regulated in human BC cell lines detected by real-time PCR and Western blotting. ZONAB expression was significantly up-regulated in BC cell lines and negatively regulated E-cadherin expression. Overexpression of ZONAB by stable transduction in human BC cell lines promoted invasion detected by transwell invasion assay. Conversely, stable suppression of ZONAB expression by RNA interference (RNAi) in BC cells attenuated invasion. A similar role of ZONAB in promoting invasion and EMT was observed in xenografts. In summary, $\mathrm{ZONAB}$ is up-regulated in $\mathrm{BC}$ cell lines and promotes invasion, demonstrating the important role it plays in tumorigenesis and cancer progression.
\end{abstract}

Key words: zonula occludens-1 associated nucleic acid binding protein, bladder cancer, tight junction protein, invasion, metastasis

Bladder cancer is one of the more common malignant urinary tumors. The incidence of bladder cancer has been increasing year by year, and the mortality rate is also high [1]. Twenty-five percent of new cases have muscle-invasive lesions that usually metastasize, even after radical cystectomy and adjuvant chemotherapy. In these cases, the 5-year survival rate is only $45-66 \%$ [2]. Mutation and dysfunction of the P53 and Rb genes, along with epithelial-to-mesenchymal transition, are commonly seen in muscle-invasive bladder cancer, which is different from what is observed in non-invasive invasive bladder cancer $[3,4]$. Unfortunately, the molecular and/or signaling changes that cancer cells have undergone as a result of these mutations, which have caused invasion into surrounding tissues, are still not clearly known.

Most of the new cases are non-muscle-invasive bladder cancer, from which $10-30 \%$ will progress to muscle lesions [5]. Intravesical instillation of Bacillus Calmette-Guerin (BCG) after transurethral resection can lower the progression rate. However, some patients do not respond to BCG intravesical instillation therapy [6], and the appearance of lower urinary tract symptoms, fever, and other adverse effects are common [7]. Intravesical chemotherapies are more commonly used in China, but their effect on lowering progression rate is not satisfactory. More experience is needed with some novel treatments, including angiogenesis inhibitors and monoclonal antibodies, to determine their effect on the inhibition of cancer progression [8]. Therefore, it is necessary to further clarify the mechanism of bladder cancer invasion with the goal of preventing tumor progression.

Tight junctions play an important role as barriers against cell migration for inhibiting the invasion and metastasis of cancer cells. The destruction of tight junctions of cancer cells leads to the loss of cell polarity, uncontrolled growth, loss of adhesion, and invasion of surrounding tissues [9]. ZONAB is a tight junction protein that also functions a transcription factor. It is regulated by the inhibitors zonula occludens-1 (ZO-1) and RalA. When tissue cell density increases, ZONAB binds to ZO-1 and is maintained in an inactive state [10]. After detachment from ZO- $1, \mathrm{ZONAB}$ is activated, enters the nucleus, where it binds specifically to the promoter of the PCNA gene to promote cell proliferation 
[11]. ZONAB expression is altered in colorectal cancers with poor prognosis [12]. ZONAB expression differs according to grades of renal cell cancer and it plays a role in promoting cancer cell proliferation and dedifferentiation [13, 14]. Studies have confirmed that ZONAB can regulate the expression of E-cadherin in gastric cancer [15], which is a key factor in maintaining cell-cell adhesion. Loss of E-cadherin expression triggers tumor invasion $[16,17]$. Studies have shown that intracellular ZONAB binds to the protein products of the BMI-1 and EZH2 genes, which play a role in invasion in different tumors [18-20]. Hence, we are curious whether ZONAB plays a role in enhancing invasion of bladder cancer.

In summary, we hypothesize that ZONAB expression is altered, and thereby enhances invasion in bladder cancer.

\section{Materials and methods}

Cell type. The human non-cancer urothelial cell line sv-huc-1 and the human bladder urothelial carcinoma cell lines T24, 5637 and UM-UC-3 were purchased from the Cell Bank of Type Culture Collection of the Chinese Academy of Sciences (Shanghai). Sv-huc-1 cells were cultured in F12K medium supplemented with $10 \%$ heat-inactivated fetal bovine serum (FBS). UM-UC-3 cells were cultured in DMEM medium supplemented with $10 \%$ heat-inactivated FBS. T24 and 5637 cells were cultured in RPMI 1640 supplemented with $10 \%$ heat-inactivated FBS. Cells were cultured at $37^{\circ} \mathrm{C}$ under $5 \% \mathrm{CO}_{2}$.

ZONAB overexpression. The human ZONAB gene sequence (NM_001145426.1) was selected from GenBank for analysis, and BLAST was used to design specific primers which were used to synthesize ZONAB (Forward, 5'-GTAAGATCGAGCGAGGAGCC-3'; reverse, 5'-TACGGTACCTTGGGCGGTA-3', Beijing Genomics Institute, Beijing, China). The target fragment and vector were double digested with BamH I and Not I in a $50 \mu \mathrm{l}$ reaction at $37^{\circ} \mathrm{C}$ for $30 \mathrm{~min}$. The DNA was purified and ligated with $10 \mu \mathrm{l}$ of T4 ligase overnight. The ligation product was transformed into Escherichia coli DH5a competent cells to construct the ZONAB overexpression lentiviral vector ( $\mathrm{pLV}-\mathrm{ZONAB}$ ). $3 \mu \mathrm{l}$ of the bacterial suspension of $\mathrm{pLV}-\mathrm{ZONAB}$ and the control group pLV-GFP-DU was inoculated into $3 \mathrm{ml}$ of LB medium with ampicillin and shaken at $37^{\circ} \mathrm{C}$ for $12 \mathrm{~h} .1 \mathrm{ml}$ of cell culture was inoculated into $30 \mathrm{ml}$ of LB medium with ampicillin for another 12 to $14 \mathrm{~h}$. Bacteria were collected and subjected to plasmid extraction following the instructions of the Qiagen Plasmid Plus Midi Kit. Plasmids containing the target gene were treated with restriction enzymes and the target was then amplified by polymerase chain reaction (PCR). DNA sequencing was performed for sequences with positive PCR results (Beijing Genomics Institute, Beijing, China). $24 \mathrm{~h}$ prior to transfection, a suitable number of HEK293T cells were seeded onto $35 \mathrm{~mm}$ Petri dishes and cell confluency reached $90-95 \%$ before transfection. The lentiviral vector was co-transfected into HEK293T cells with the human CMV promoters $\mathrm{pH} 1$ and $\mathrm{pH} 2$. Cell culture supernatants containing virus were collected $48 \mathrm{~h}$ after transfection and the virus was purified using the PEG6000 virus purification kit. One day before transduction, T24 cells were plated onto $35 \mathrm{~mm}$ Petri dishes and allowed to reach a cell density of about $80 \%$ when infected. $100 \mu \mathrm{l}$ of the lentivirus suspension was added to $100 \mu \mathrm{l}$ of RPMI1640 medium and polybrene was added to a final concentration of $6 \mu \mathrm{g} / \mu \mathrm{l}$. The original cell culture medium was replaced with virus infection solution and placed into the cell incubator for $24 \mathrm{~h}$ before replacement with fresh medium. Puromycin was added to a final concentration of $1 \mu \mathrm{g} / \mathrm{ml}$ after incubation for $24 \mathrm{~h}$. Expression of green fluorescent protein (GFP) was observed under a fluorescence microscope. After 14 days of screening, cells were frozen and ZONAB expression was examined. Cells were divided into three groups: experimental group T24-ZONAB, negative control group T24-GFP, blank control group T24-P.

ZONAB shRNA. The human ZONAB gene coding region (NM_001145426.1) was selected in GenBank for analysis. 5 interference target sequences (sh/ZONAB-1: 5'-ACGGAAATATCTGCGCAGT-3'; sh/ZONAB-2: 5'-GTTGGAGAGGCTGAAGATA-3'; sh/ZONAB-3: 5'-CCTTCACAAGATGGCAAAG-3'; sh/ZONAB-4: 5'-ACGGAAGACAAGAGAGTAG-3'; sh/ZONAB-5: 5'-GTGCTAAACCTCCAAGTGT-3') and one negative control target sequence (sh/Con: 5'-ATCGACTAGCCACTTAGAC-3') were designed and synthesized (Genescript Biotech Co., Ltd, Nanjing, China). Sequence alignment in BLAST was used to make sure that the selected interference sequences did not share homology with other genes from corresponding genomic data (human, mouse, rat, etc.). The above 6 pairs of oligonucleotide sequences were annealed and ligated with pLV-shRNA linearized vector digested with BamH I and EcoR I to construct lentiviral vector plasmids, respectively, which were confirmed by sequencing (Genescript Biotech Co., Ltd.). Escherichia coli were transfected with the constructed lentiviral vector plasmid, and a large number of plasmids were extracted according to the instructions of Qiagen Plasmid Plus Midi Kit. An appropriate number of HEK293T cells were inoculated in a $90 \mathrm{~mm}$ dish $24 \mathrm{~h}$ prior to transduction. 5 groups of ZONAB RNA interference lentiviral vectors, and 1 control group of virus vector, were co-transfected with $\mathrm{pH} 1$ and $\mathrm{pH} 2$ into six groups of HEK293T cells, respectively. 5 groups of the ZONAB RNA interference virus, and 1 group of control virus, were packaged and purified with the PEG6000 virus purification kit. UM-UC-3 cells were plated into 35-mm Petri dishes and grown to a cell density of about $80 \%$ when infected. $300 \mu$ l of lentivirus suspension was added to $1.7 \mathrm{ml}$ DMEM medium, and polybrene was added to a final concentration of $6 \mu \mathrm{g} / \mu \mathrm{l}$. The cells were homogenized and prepared as the virus infection solution. The original DMEM medium was replaced with virus infection solution and puromycin was added to a final concentration of $0.3 \mu \mathrm{g} / \mathrm{ml}$. After 14 days of screening, cells were 
frozen and ZONAB expression was examined by Western blotting. The most effective RNAi target sequence group of the ZONAB gene, which was sh/ZONAB-3: 5'-CCTTCACAAGATGGCAAAG-3', was selected as the experimental group according to the inhibition rate of ZONAB expression. The cells were divided into three groups: ZONAB RNA interference experimental group UM-UC-3-R, negative control group UM-UC-3-N, and untransduced blank control group UM-UC-3-P.

Western blotting. An appropriate volume of RIPA cell lysate was added to the tissue samples or cells. After centrifugation, the protein concentration of the supernatant was determined using the bicinchoninic acid (BCA) protein concentration assay kit (Beyotime, Shanghai, China). A $5 \times$ Loading Buffer was used to dilute the protein samples, which were boiled in a water bath for $5 \mathrm{~min}$. Proteins were separated by SDS-PAGE and subsequently transferred to a polyvinylidene difluoride (PVDF) membrane (Millipore, USA). After incubation with primary $(1: 1000)$ and secondary antibodies (1:5000), respectively, the electrochemical luminescence (ECL) solution (Sigma, St. Louis, MO) was added for substrate luminescence and the band intensity was analyzed by a digital scanning imaging system.

RNA expression analysis. Semi-quantitative RT-qPCR was used to detect RNA expression. The collected cell samples were washed twice with phosphate buffered saline (PBS). The tissue samples were frozen in liquid nitrogen and ground to a powder. Trizol reagent (Invitrogen, Carlsbad, CA, USA) was added to samples to extract total RNA. The extracted RNA absorbance was measured using a spectrophotometer to calculate concentration. Total RNA was reverse transcribed into cDNA by Prime Script RT Master Mix kit (Takara Biotechnology Co., Ltd., Japan) according to the manufacturer's instructions. Real-Time PCR was performed with cDNA as the template using the SYBR Premix Ex Taq II kit (Takara Biotechnology Co., Ltd., Japan) in AriaMx real-time fluorescence PCR system (Agilent, USA). The reaction system was prepared according to the manufacturer's protocol. PCR amplification conditions were as follows: $95^{\circ} \mathrm{C}$ denaturation $30 \mathrm{~s}, 45$ PCR cycles $\left(95^{\circ} \mathrm{C} 5 \mathrm{~s}\right.$; $\left.60^{\circ} \mathrm{C} 20 \mathrm{~s}\right), 65^{\circ} \mathrm{C}$ extended $10 \mathrm{~s}$, and $65^{\circ} \mathrm{C}$ fluorescence signal detection, to obtain the standard curve. GAPDH mRNA was used as an internal control and $\mathrm{H}_{2} \mathrm{O}$ was used as a negative control. Primer sequences were as follows: ZONAB upstream: 5'-GCTGGGGAGGAGGAGGA-3', downstream: 5'-CTGTTGGGATGGGGTAAGAC-3'; E-cadherin upstream: 5'-GACCAAGTGACCACCTTAGA-3', downstream: 5'-GCAGGAATTTGCAATCCTGCT-3'; GAPDH upstream: 5'-TCCCTGAGCTGAACGGGAAG-3', downstream: 5'-GGAGGAGTGGGTGTCGCTGT-3'. The relative expression levels of the ZONAB, E-cadherin, and GAPDH genes were obtained according to the standard curve. Statistical analysis was performed using $2^{-\Delta \Delta C T}$.

Immunohistochemistry. Tissues were fixed in formalin, embedded in paraffin, sectioned at a thickness of $5 \mu \mathrm{m}$, dewaxed, rehydrated, and put in sodium citrate with microwave for antigen retrieval. A non-specific stain blocking agent was added to slides, which were then incubated for $30 \mathrm{~min}$ at room temperature. Anti-human ZONAB primary antibody (Thermo Fisher, Shanghai, China, dilution 1: 200) or anti-human E-cadherin primary antibody (Thermo Fisher, Shanghai, China, dilution 1: 500) was added and incubated overnight at $4^{\circ} \mathrm{C}$. After being washed with PBS, the slides were incubated with secondary antibody (Gene Tech, Shanghai, China, dilution 1:100) for $30 \mathrm{~min}$ at room temperature. Excess secondary antibody was washed off. Slides were incubated with streptavidin-ABC, developed with diaminobenzaminidine (DAB), washed with running water, counterstained with hematoxylin, dehydrated with gradient alcohol, dried, mounted with neutral balsam. Tissue morphology was observed and photographed under the microscope and compared with known positive sections. The results were interpreted blindly by 2 pathologists. 5 high power fields (original magnification $\times 400$ ) were randomly selected for each section, and 200 cells were observed in each field. Semi-quantitative results were obtained by determining the intensity and scale of cell staining. Cells with cytoplasm or nucleus stained yellow or dark brown were defined as positive cells. Cell staining intensity score was as follows: 0 for no staining, 1 for weak staining, 2 for moderate staining, and 3 for strong staining. Cell staining scale score was as follows: 0 for positive cells $\leq 5 \%, 1$ for $6-25 \%, 2$ for $6-50 \%$, 3 for $51-75 \%$ and 4 for $>75 \%$. The composite staining score (cell staining intensity score + cell staining scale score) 2 points were considered negative staining (low staining), 3 to 4 points were considered moderate staining, and 5 to 6 points were considered high staining.

Invasion assay. A transwell invasion assay was performed using 24-well transwell chambers with $8 \mu \mathrm{m}$ pore size polycarbonate membranes (Corning, NY, USA). Before the experiment, the upper chamber was covered with a Matrigel filtration membrane (1:10 dilution, BD Biosciences, Bedford, MA, USA) that stayed overnight. The cells were seeded in whole serum for confluence and cultured in serum-free medium for 16 h. $0.2 \mathrm{ml}$ cell culture medium containing $1 \%$ fetal bovine serum was added to each well and $1 \times 10^{5}$ pre-treated cells were added. $0.9 \mathrm{ml}$ cell culture medium containing $10 \%$ fetal bovine serum was added to each well in the lower chamber as chemotactic agent. After incubated at $37^{\circ} \mathrm{C}$ for $36 \mathrm{~h}$, cells on the upper surface of the upper chamber which didn't infiltrate into the membrane were removed with the cotton swab. The cells that infiltrated into the lower surface of the filter membrane were fixed with $4 \%$ paraformaldehyde solution and stained with crystal violet. 5 fields at $400 \times$ magnification were randomly selected. The number of cells that invaded the lower chamber was counted. The average cell number was defined as the relative cell number per field. The experiment was repeated three times.

Tumor xenograft study. The study was approved by the Medical Laboratory Animal Welfare and Ethics Committee 
of China Medical University and operated according to the proper guidelines. A total of 30 experimental animals were used. A total of $2.5 \times 10^{6}$ bladder cancer cells (T24-ZONAB, T24-GFP and T24-P, respectively) were suspended in $200 \mu \mathrm{l}$ of PBS. The mixture was injected subcutaneously into the flank of 8 -week old BALB/c-nu/nu mice ( 8 mice per group, purchased from Beijing Vital River Laboratory Animal Technology Company, Beijing, China). Tumor size was measured by vernier caliper every 7 days and tumor volume was calculated according to the formula: volume $=\left[\right.$ width $^{2}$ $\times$ length] / 2. Mice were examined by small animal in vivo imaging after six weeks (In vivo MS FX Pro, Carestream, USA) and then humanely sacrificed. The tumor lesion, liver, and lungs of mice were resected, and the surface of the liver and lungs were examined for metastatic lesions. The resected tissue was fixed in $10 \%$ formalin, embedded in paraffin, sectioned at a thickness of $3 \mu \mathrm{m}$, stained with hematoxylin \& eosin (H \& E), and observed by light microscopy (Olympus, Tokyo, Japan).

Statistical analysis. Statistical analysis was performed using SPSS 19.0 software (China Medical University, Shenyang, China). Results of each assay were obtained after three repeated independent experiments and expressed as mean \pm standard deviation (SD). The two groups of numerical data were compared by Student's t-test. The statistical difference between more than two groups was compared by one-way ANOVA and post hoc Tukey's multiple comparison test. The difference between the two groups of categorical data was compared by Chi-square analysis. A p-value $<0.05$ indicated that the difference was statistically significant. Correlation analysis of the data was processed using Spearman rank order correlation coefficient.

\section{Results}

ZONAB is up-regulated and E-cadherin is downregulated in bladder cancer cell lines. The composition of adhesion and tight junction proteins are often altered in solid tumors; in particular, the expression of E-cadherin and claudin-6, which are typical proteins that maintain the epithelial phenotype, is down-regulated [21, 22]. To test the hypothesis that expression of ZONAB, another tight junction-associated protein, may be altered in bladder cancer, ZONAB expression was analyzed in urothelial carcinoma cell lines and tissue samples. The expression of ZONAB mRNA in the human bladder cancer cell lines T24, 5637 and UM-UC-3 was first detected by real-time PCR. As control, the expression of ZONAB mRNA in the human non-cancer urothelial cell line sv-huc-1 was examined. The expression of ZONAB mRNA was significantly increased in bladder cancer cell lines (T24: $3.7 \pm 0.7,5637: 4.2 \pm 0.8$, UM-UC-3: 5.3 \pm 0.6 ) over that of non-cancer urothelial cell line sv-huc-1 $(1.0 \pm 0.2$, $\mathrm{p}<0.05$, Figure $1 \mathrm{~A})$. In order to confirm whether ZONAB protein expression level reflects the mRNA expression level, ZONAB protein expression was examined in sv-huc-1,
T24, 5637 and UM-UC-3 cell lines by Western blotting. Expression of ZONAB protein was significantly increased in bladder cancer cell lines (T24: 1.7 $\pm 0.2,5637: 2.3 \pm 0.3$, UM-UC-3: $3.5 \pm 0.4)$ compared to non-cancer urothelial cell line sv-huc-1 $(1.0 \pm 0.1, \mathrm{p}<0.05$, Figure $1 \mathrm{~B})$. In order to identify the expression pattern of E-cadherin in bladder cancer cell lines with different expression level of ZONAB, the expression of E-cadherin mRNA in sv-huc-1, T24, 5637 and UM-UC-3 cell lines was detected by real-time PCR. The expression of E-cadherin mRNA was significantly decreased in bladder cancer cell lines (T24: 0.42 $\pm 0.02,5637: 0.39 \pm 0.02$, UM-UC-3: $0.06 \pm 0.01)$ compared to normal urothelial cell lines $(1.0 \pm 0.2, \mathrm{p}<0.05$, Figure $1 \mathrm{C})$, which is the opposite of the ZONAB mRNA expression results. Expression of E-cadherin protein was significantly decreased detected by Western blotting in bladder cancer cell lines (T24: $0.8 \pm 0.1$, 5637: 0.8 \pm 0.1 , UM-UC-3: $0.7 \pm 0.1)$ compared to non-cancer urothelial cell line sv-huc-1 $(1.0 \pm 0.1, \mathrm{p}<0.05$, Figure 1D), which reflects the mRNA expression pattern.

Invasion of cancer cells was promoted following ZONAB up-regulation. The above findings suggest that increased expression of ZONAB is observed in bladder cancer, which makes us curious whether the increased expression of ZONAB promotes the invasion of bladder cancer or is just correlated with malignant transformation. The human bladder cancer cell line T24 was chosen as the subject for stable transduction of ZONAB overexpression because of its invasive ability, and relatively low expression level of ZONAB compared to other bladder cancer cell lines. T24 cells were transfected with lentiviruses packaged with the ZONAB-expressing vector pLV-ZONAB. T24 cells stably expressing ZONAB were identified. Polyclonal T24 cells stably expressing WT ZONAB along with green fluorescence were obtained and named T24-ZONAB (Figure 2A). The expression of the ZONAB protein was significantly higher in T24-ZONAB cells than in blank control group cells (T24-P), or in the negative control group cells (T24-GFP) as detected by Western blotting $(\mathrm{p}<0.05$, Figure $2 \mathrm{~B})$. The number of invasive cells that passed through the Matrigel membrane in the T24-ZONAB group $(34.1 \pm 5.2 / \mathrm{HP})$ was significantly higher than in the T24-P $(10.2 \pm 4.1 / \mathrm{HP})$, or T24-GFP $(8.1 \pm 3.1 / \mathrm{HP})$ groups $(\mathrm{p}<0.05$, Figure $2 \mathrm{C})$, indicating that invasive ability of T24-ZONAB (Figure 2E) is stronger than T24-P (Figure 2D) and T24-GFP (Figure 2F) when measured by the transwell chamber invasion assay. The above findings suggest that ZONAB overexpression can enhance invasion of bladder cancer cells.

ZONAB down-regulation attenuated invasion of bladder cancer cells. The above findings suggest that ZONAB overexpression can promote invasion of bladder cancer cells. We further investigated whether reduced ZONAB expression can inhibit invasion of bladder cancer. UM-UC-3 cells were stably-transfected by the RNAi technique to downregulate $\mathrm{ZONAB}$ expression. The expression of the ZONAB protein in UM-UC-3-R cells was $36 \%$ of that observed in the 
untransduced control group cells (UM-UC-3-P) as detected by Western blotting $(\mathrm{p}<0.05$, Figure $3 \mathrm{~A})$, suggesting that expression of the ZONAB protein was stably down-regulated in the UM-UC-3-R cells. There was no significant difference in ZONAB protein expression between the negative control (UM-UC-3-N) and blank control (UM-UC-3-P) groups $(p<0.05$, Figure $3 \mathrm{~A})$. The number of invasive cells passing through the Matrigel membrane was significantly lower in UM-UC-3-R $(13.1 \pm 2.8 / \mathrm{HP})$ cells, than in UM-UC-3-P $(35.4 \pm 2.7 / \mathrm{HP})$ or UM-UC-3-N (32.2 $\pm 3.0 / \mathrm{HP}$, $\mathrm{p}<0.05$, Figure $3 \mathrm{~B}$ ) cells, suggesting that invasive ability of UM-UC-3-P (Figure 3C), and UM-UC-3-N (Figure 3D) cells was attenuated following ZONAB down-regulation in UM-UC-3-R cells (Figure 3E) as detected by the transwell chamber invasion assay. The invasive ability of bladder cancer cells was significantly attenuated following ZONAB down-regulation.

Up-regulation of ZONAB enhances growth and invasion of bladder cancer in xenograft nude mice. Since the invasive ability of ZONAB-overexpressing T24-ZONAB
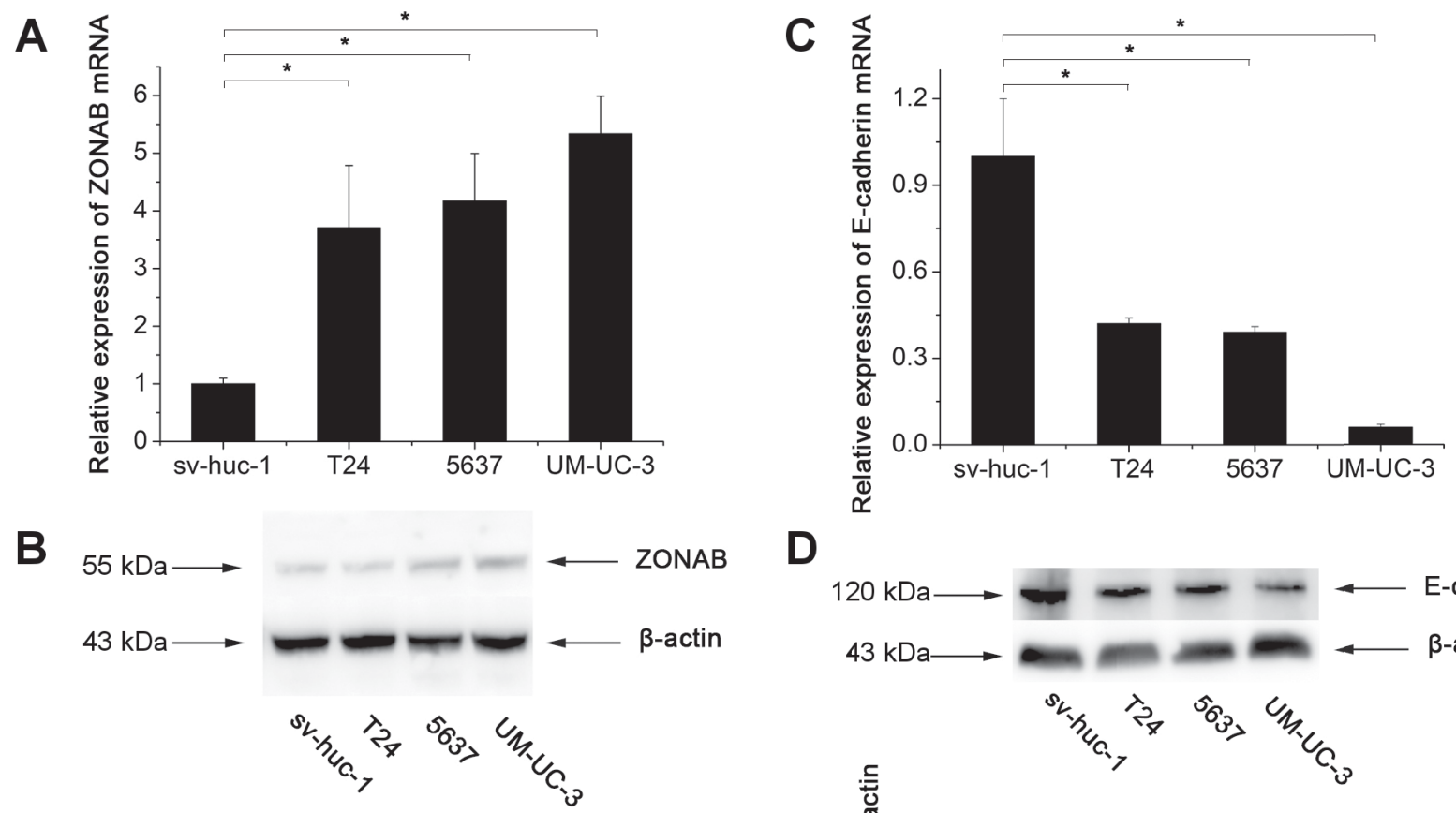

D
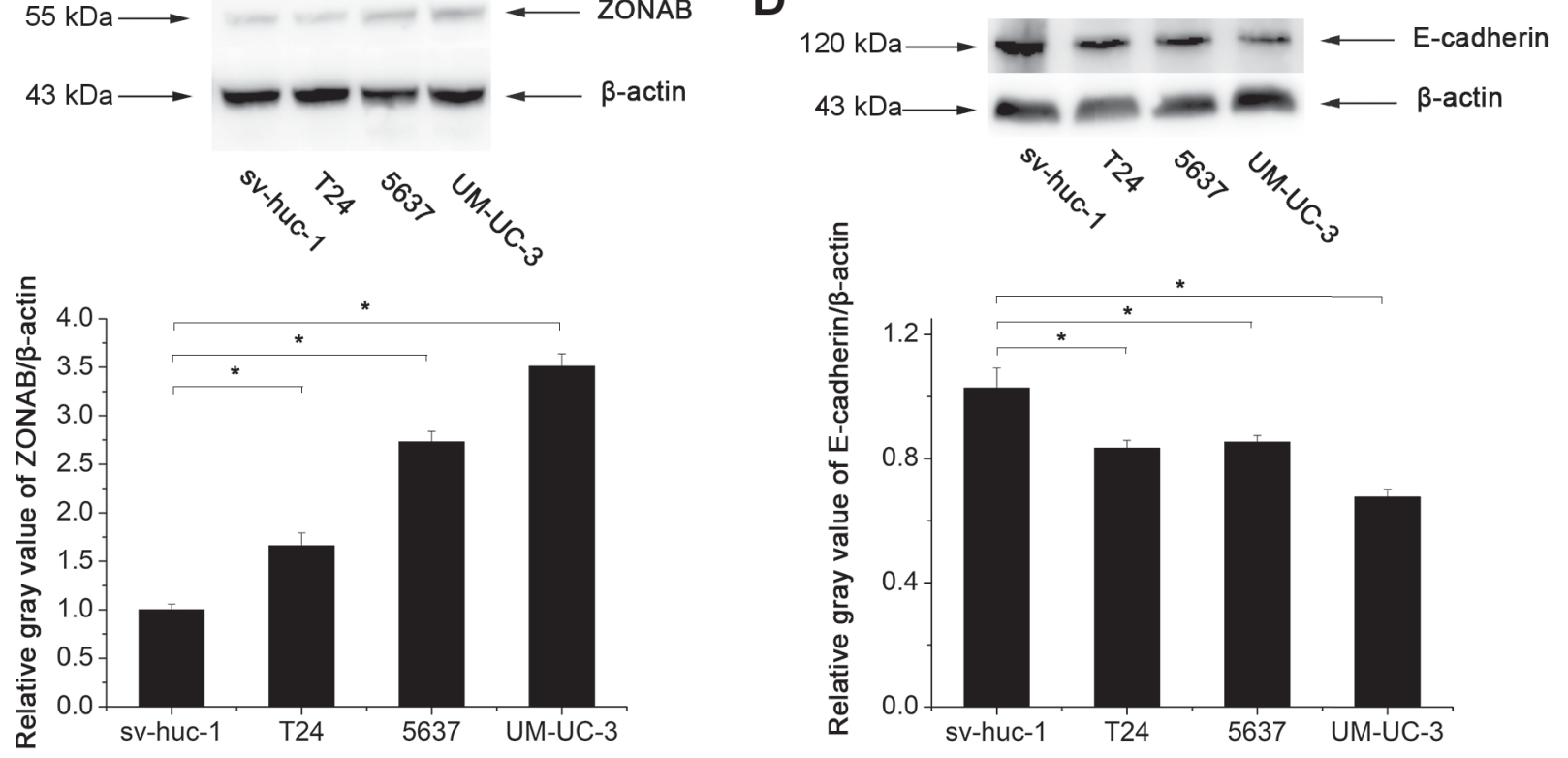

Figure 1. ZONAB expression was up-regulated and E-cadherin expression was down-regulated in bladder cancer cell lines. A) The expression of ZONAB mRNA in non-cancer cell line (sv-huc-1) and bladder cancer cell lines (T24, 5637, UM-UC-3) was detected by real-time PCR. Relative expression adjusted to the reference gene GAPDH and then standardized to sv-huc-1 (non-cancer urothelial cell line) is shown (mean $\pm \mathrm{SD})$. ${ }^{*} \mathbf{p}<0.05$, one-way ANOVA, post hoc Tukey's test. B) The expression of ZONAB protein in non-cancer cell line (sv-huc-1) and bladder cancer cell lines (T24, 5637, UMUC-3) was detected by Western blotting. Relative gray value adjusted to the internal control $\beta$-actin and then standardized to sv-huc-1 (non-cancer urothelial cell line) is shown (mean $\pm \mathrm{SD}) .{ }^{*} \mathrm{p}<0.05$, one-way ANOVA, post hoc Tukey's test. C) The expression of E-cadherin mRNA in non-cancer cell line (sv-huc-1) and bladder cancer cell lines (T24, 5637, UM-UC-3) was detected by real-time PCR. Relative expression adjusted to the reference gene GAPDH and then standardized to sv-huc-1 is shown (mean \pm SD). ${ }^{*} \mathrm{p}<0.05$, one-way ANOVA, post hoc Tukey's test. D) The expression of E-cadherin protein in non-cancer cell line (sv-huc-1) and bladder cancer cell lines (T24, 5637, UM-UC-3) was detected by Western blotting. Relative gray value adjusted to the internal control $\beta$-actin and then standardized to sv-huc-1 (non-cancer urothelial cell line) is shown (mean $\pm \mathrm{SD})$. ${ }^{*} \mathrm{p}<0.05$, one-way ANOVA, post hoc Tukey's test. 
cells was enhanced when studied in vitro, we wondered whether ZONAB also promoted invasion in vivo. Xenograft tumor models were made by injecting T24-P, T24-GFP, and T24-ZONAB cells, respectively, into athymic mice (nude mice) (Figure 4A). $2.5 \times 10^{6}$ cells in $200 \mu \mathrm{l}$ PBS were injected subcutaneously into the dorsal flank of nude mice. Tumor lesions were detected in three groups at 10 days after injection. The tumor growth rate was significantly higher in the T24-ZONAB group than in the T24-GFP or T24-P groups with a tumor volume of $1374.9 \pm 316.6 \mathrm{~mm}^{3}, 630.5 \pm 110.2 \mathrm{~mm}^{3}$, and

\section{A}

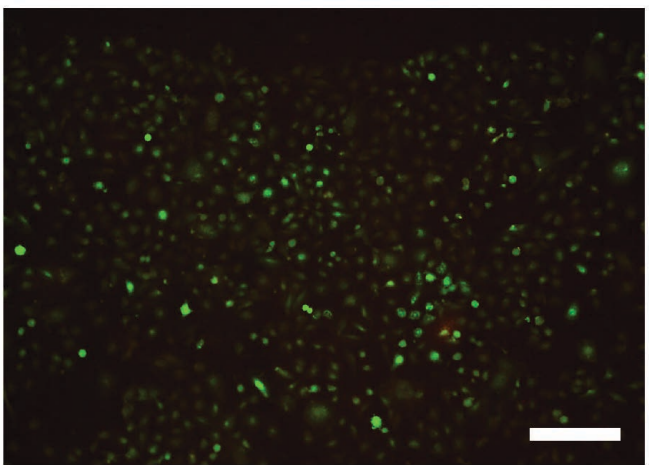

B
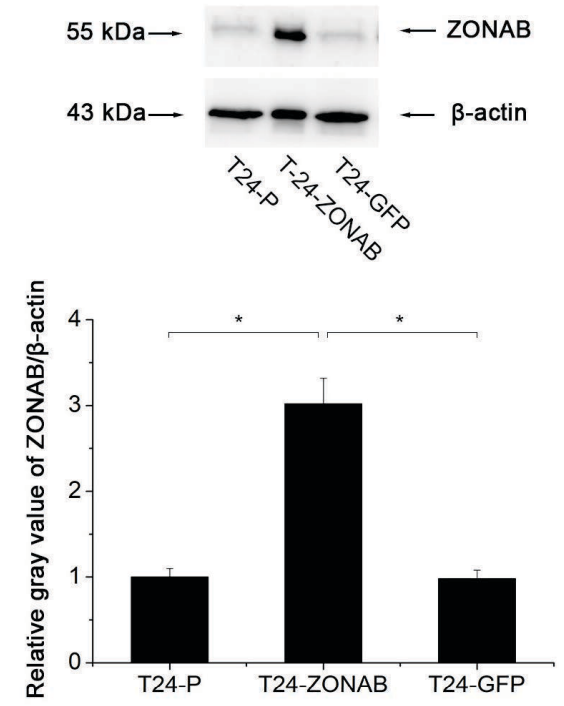

C

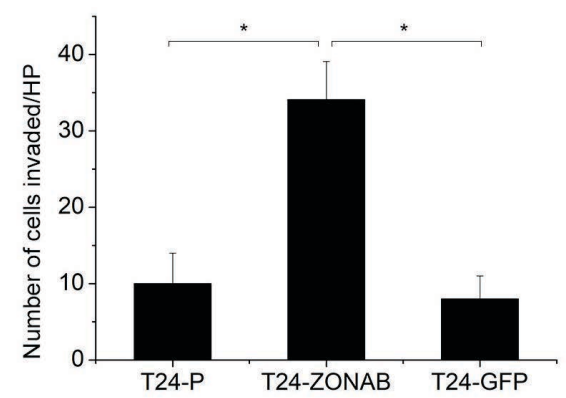

D

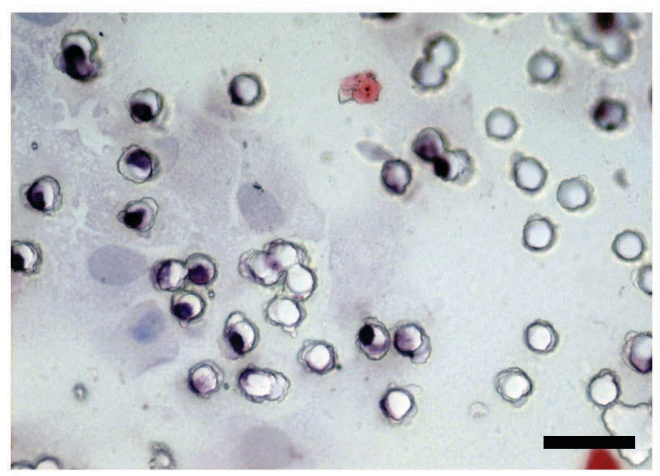

E

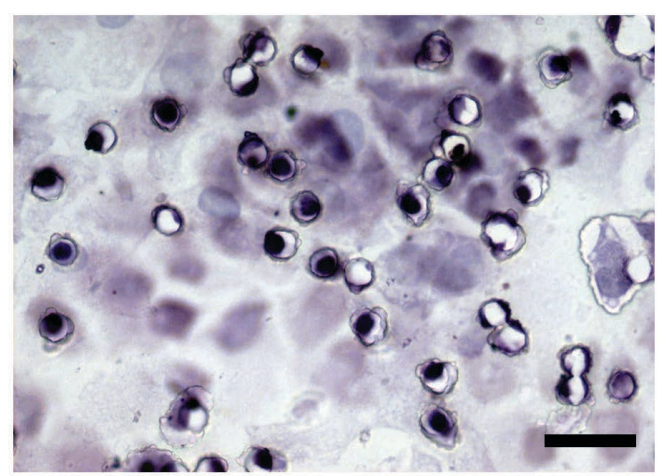

$\mathbf{F}$

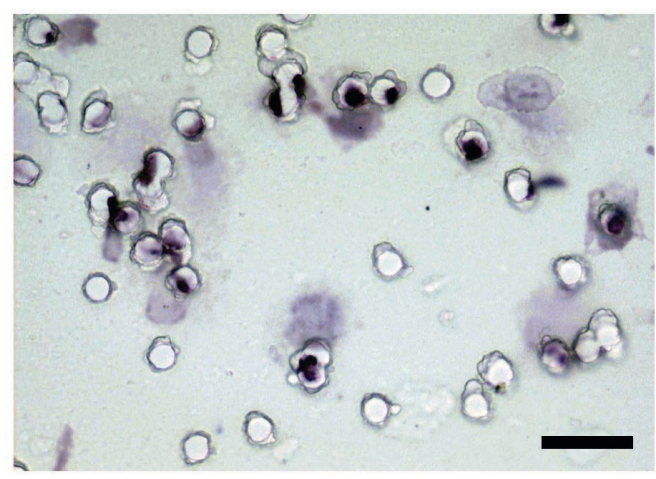

Figure 2. Invasion of cancer cells was promoted following ZONAB up-regulation. A) Green fluorescence of T24-ZONAB cells after stable transduction by $\mathrm{ZONAB}$ overexpressing lentiviral vectors was observed under a fluorescence microscope, indicating a stable overexpression of $\mathrm{ZONAB}$ in $\mathrm{T} 24$ ZONAB cells (original magnification $\times 100$. Scale bar, $200 \mu \mathrm{m}$ ). B) The expression of ZONAB protein in T24-P, T24-ZONAB and T24-GFP detected by Western blotting. Relative gray value adjusted to the internal control $\beta$-actin and then standardized to T24-P (untransduced T24 cell line) is shown (mean \pm SD). ${ }^{*}$ p $<0.05$, one-way ANOVA, post hoc Tukey's test. C) Invasive cell numbers of T24-P, T24-ZONAB and T24-GFP were measured using transwell chamber invasion assay (mean \pm SD). ${ }^{\star} \mathbf{p}<\mathbf{0 . 0 5}$, one-way ANOVA, post hoc Tukey's test. D) H\&E staining of T24-P cells in the lower chamber after transwell chamber invasion assay (original magnification $\times 400$. Scale bar, $50 \mu \mathrm{m}$ ). E) $\mathrm{H} \& \mathrm{E}$ staining of T24-ZONAB cells in the lower chamber after transwell chamber invasion assay (original magnification $\times 400$. Scale bar, $50 \mu \mathrm{m}$ ). F) H\&E staining of T24-GFP cells in the lower chamber after transwell chamber invasion assay (original magnification $\times 400$. Scale bar, $50 \mu \mathrm{m}$ ). 

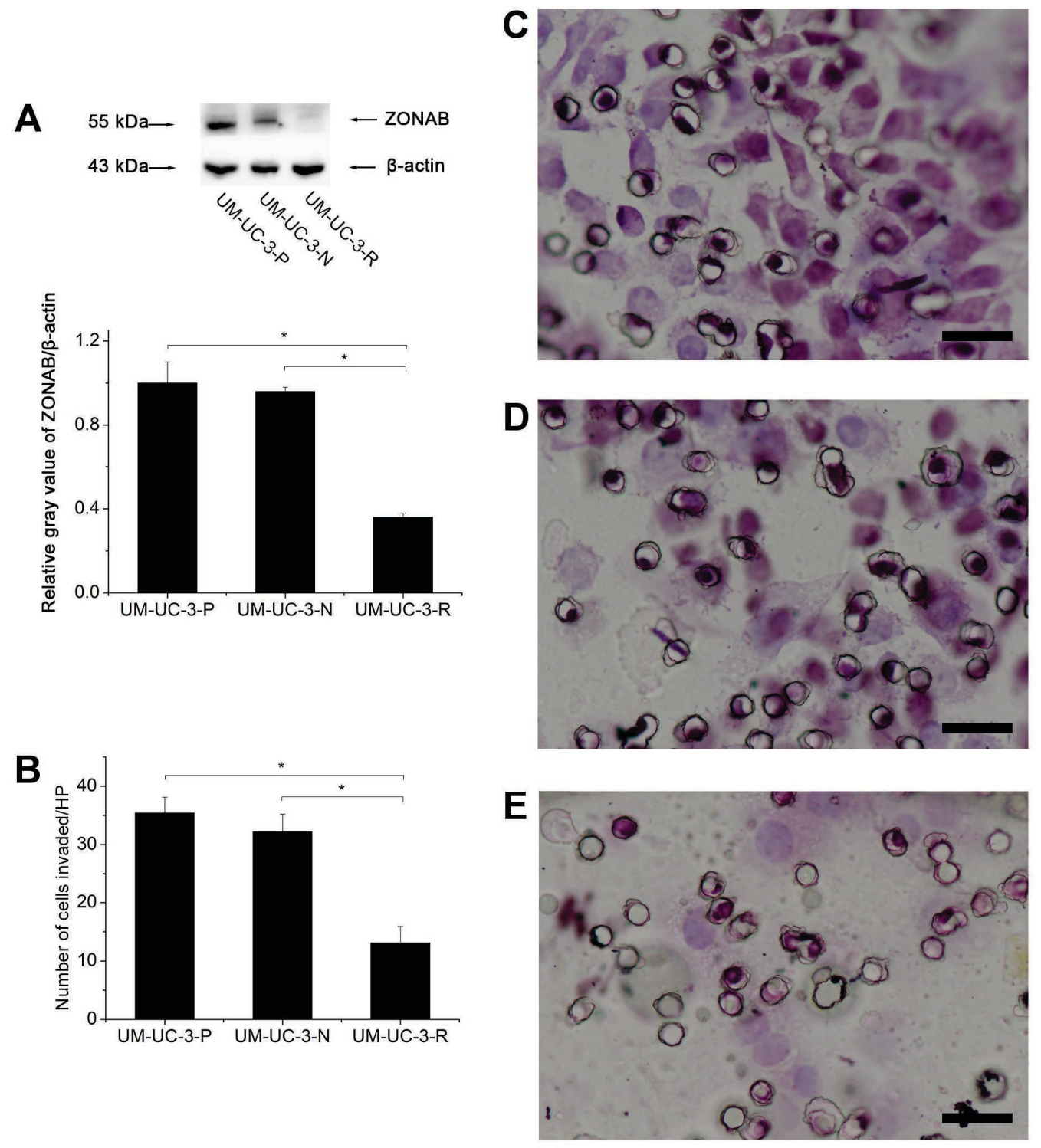

Figure 3. ZONAB down-regulation attenuated invasion of bladder cancer cells. A) The expression of ZONAB protein in UM-UC-3-P, UM-UC-3-N and UM-UC-3-R as detected by Western blotting. Relative gray value adjusted to the internal control $\beta$-actin and then standardized to UM-UC-3-P (untransduced T24 cell line) is shown (mean $\pm \mathrm{SD}$ ). ${ }^{\star} \mathrm{p}<0.05$, one-way ANOVA, post hoc Tukey's test. B) Invasive cell numbers of UM-UC-3-P, UM-UC-3-N and UM-UC-3-R were measured using transwell chamber invasion assay (mean \pm SD). ${ }^{*} \mathbf{p}<0.05$, one-way ANOVA, post hoc Tukey's test. C) H\&E staining of UM-UC-3-P cells in the lower chamber after transwell chamber invasion assay (original magnification $\times 400$. Scale bar, $50 \mu \mathrm{m}$ ). D) H\&E staining of UM-UC-3-N cells in the lower chamber after transwell chamber invasion assay (original magnification $\times 400$. Scale bar, $50 \mu \mathrm{m}$ ). E) H\&E staining of UM-UC-3-R cells in the lower chamber after transwell chamber invasion assay (original magnification $\times 400$. Scale bar, $50 \mu \mathrm{m}$ ).

$588.7 \pm 95.5 \mathrm{~mm}^{3}$, respectively, at 6 weeks ( $\mathrm{p}<0.05$, Figure $\left.4 \mathrm{~B}\right)$. A trend of there being a more obvious difference in tumor volume was evident over time. The results above demonstrate that overexpression of ZONAB can promote proliferation of bladder cancer cells. Because the in vitro results suggested that ZONAB can promote invasion of bladder cancer cells, we decided to determine whether ZONAB could enhance bladder cancer invasion in vivo. Histological examination of $\mathrm{H} \& \mathrm{E}$ stained slides from implanted tumor lesions demon- strated an invasion rate of $66.7 \%(4 / 6)$ into adjacent striated muscles in the T24-ZONAB group (Figure 4E), compared to no invasion into peripheral tissues in the T24-GFP group $(0 / 6, \mathrm{p}<0.05$, Figure $4 \mathrm{D})$ and T24-P group $(0 / 6, \mathrm{p}<0.05$, Figure 4C). Similarly, $2.5 \times 10^{6}$ of UM-UC-3-P, UM-UC-3-N, and UM-UC-3-R cells in $200 \mu \mathrm{l}$ PBS were injected subcutaneously, respectively, into the dorsal flank of nude mice. However, no tumor lesions at all had formed by 20 days after injection (Data not shown). The above results suggest that 

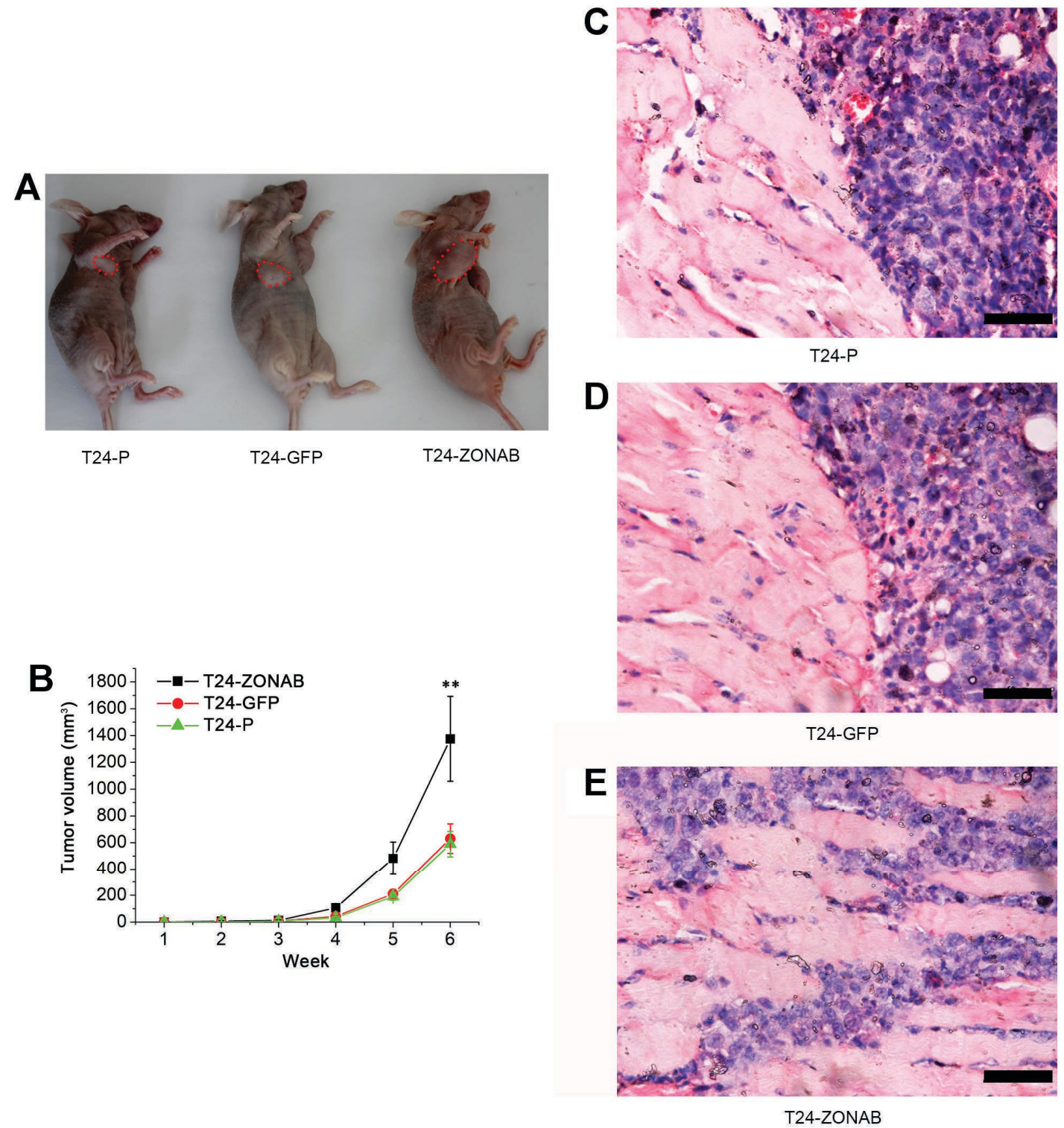

Figure 4. ZONAB promotes tumor growth and invasion in xenograft nude mice. A) $2.5 \times 10^{6}$ T24-P $(n=6)$, T24-GFP $(n=6)$ and T24-ZONAB (n=6) cells were implanted subcutaneously in the dorsal flank of 8-week-old nude mice. Red dotted lines show the tumor location after 6 weeks of cell implantation. B) Tumor growth rate was represented by tumor volume which was calculated by regularly measured tumor diameter $\left(\right.$ volume $=\left[\text { width }{ }^{2} \times \text { length }\right]^{2}$ / 2) (mean volume \pm standard error, ${ }^{* *} \mathbf{p}<0.05$, one-way ANOVA, post hoc Tukey's test). C) H\&E staining of implanted tumor lesions with T24-P cells. No invasion into the striated muscle was found at the tumor margin (original magnification $\times 400$. Scale bar, $50 \mu \mathrm{m}$ ). D) $\mathrm{H} \& \mathrm{E}$ staining of implanted tumor lesions with T24-GFP cells. No invasion into the striated muscle was found at the tumor margin (original magnification $\times 400$. Scale bar, $50 \mu \mathrm{m}$ ). $\mathrm{E}$ ) H\&E staining of implanted tumor lesions with T24-ZONAB cells. Multiple clusters of invaded cancer cells were found in the striated muscle adjacent to the tumor lesion (original magnification $\times 400$. Scale bar, $50 \mu \mathrm{m}$ ).

the invasion-regulating ability of ZONAB is not biased by in vitro cell culture but is an outcome of alteration of ZONAB expression. ZONAB promotes invasion of bladder cancer both in vitro and in vivo. Obvious fluorescence was detected from primary tumor lesions of the T24-ZONAB xenograft tumor models using a small animal live body imaging system, indicating that ZONAB was highly expressed in primary tumor lesions, but no distant metastatic lesions were found
(Figure 5 A, B). Similarly, no metastatic lesions were found by gross examination, and microscopic examination of slides with $\mathrm{H} \& \mathrm{E}$ staining of lung and liver tissues from xenograft tumor models (Figure $5 \mathrm{C}, \mathrm{D}$ ).

ZONAB expression enhances tumor invasion phenotype. In order to identify the role of ZONAB expression on tumor invasion phenotype, the expression of E-cadherin mRNA following ZONAB up-regulation and down-regula- 
A

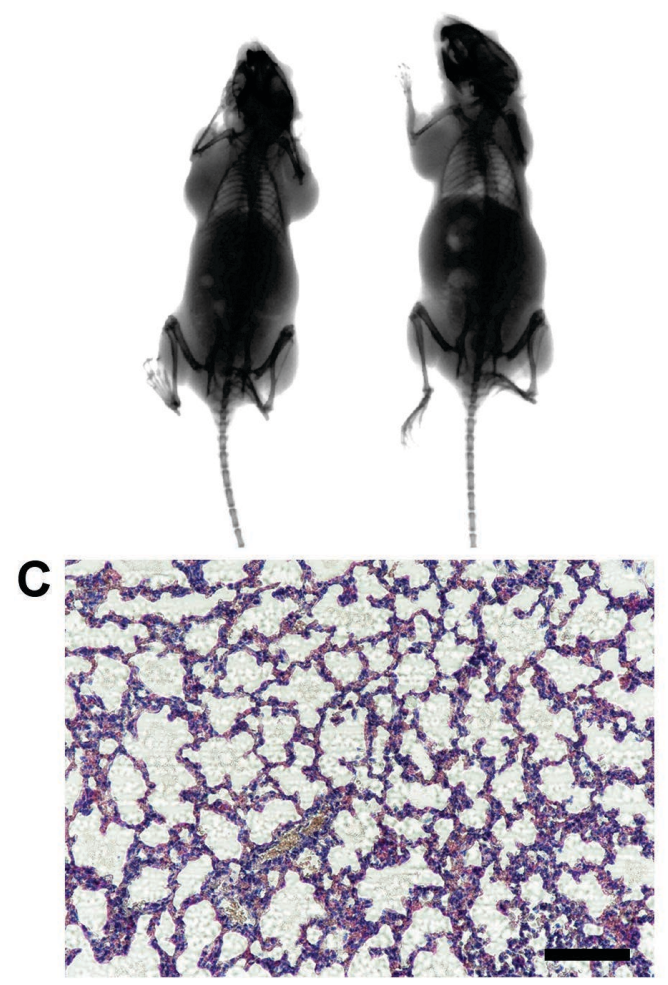

B

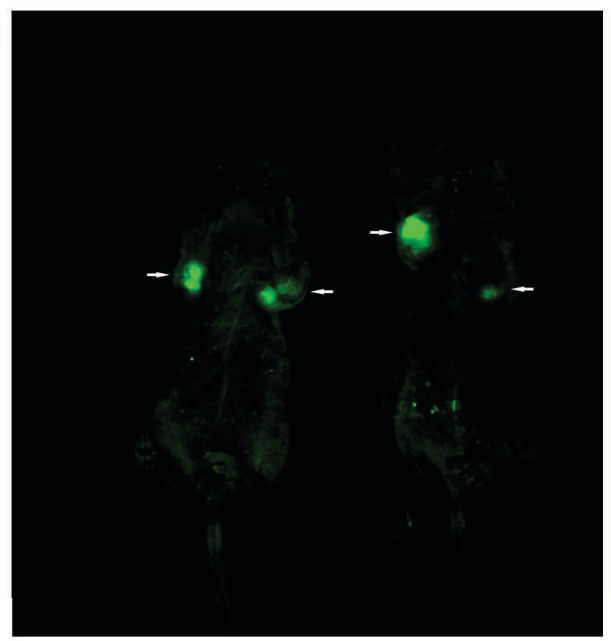

D

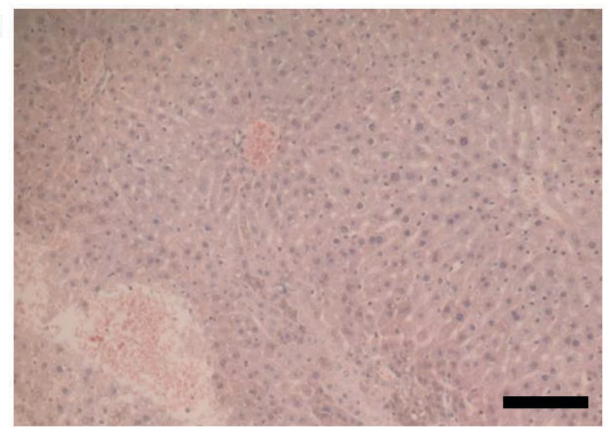

Figure 5. No distinct metastasis was found following ZONAB up-regulation in xenograft nude mice. A) X-ray imaging of xenograft nude mice implanted with T24-ZONAB cells. B) Fluorescent imaging of xenograft nude mice implanted with T24-ZONAB cells taken simultaneously with X-ray imaging. White arrow shows obvious green fluorescence at the tumor site, suggesting that ZONAB is strongly expressed at implanted tumor site but no significant distant metastases were found. C) H\&E staining of the lung tissue in xenograft model implanted with T24-ZONAB cells. No metastatic lesion was found in the lung tissue (original magnification $\times 100$. Scale bar, $200 \mu \mathrm{m}$ ). D) $\mathrm{H} \& \mathrm{E}$ staining of the liver tissue in xenograft model implanted with T24-ZONAB cells. No metastatic lesion was found in the liver tissue (original magnification $\times 100$. Scale bar, $200 \mu \mathrm{m}$ ).

tion was detected by real-time PCR. After transduction of ZONAB in T24 cell line to make ZONAB overexpression, E-cadherin mRNA was significantly decreased $(\mathrm{p}<0.05$, Figure 6A). Similarly, the expression of the E-cadherin protein in T24-ZONAB cells was $47 \%$ of that observed in the negative control group cells (T24-GFP) as detected by Western blotting $(\mathrm{p}<0.05$, Figure $6 \mathrm{~B})$, suggesting that expression of the E-cadherin was down-regulated following ZONAB up-regulation. Furthermore, after downregulation of ZONAB in UM-UC-3 cell line by RNA interference E-cadherin mRNA was significantly increased $(p<0.05$, Figure $6 C)$. The expression of E-cadherin protein in UM-UC-3-R cells also reflected the mRNA results above $(p<0.05$, Figure 6D). Immunohistochemical staining of xenograft tumor revealed in vivo that high expression rate of E-cadherin in T24-ZONAB group (Figure 7C) was significantly higher than that in T24-P (Figure 7A) or T24-GFP (Figure 7B) $(p<0.05$, Figure 7D). Down-regulation of E-cadherin expression in cancer cells is key factor of tumor invasion. Adhesion between cells is weakened and the epithelial cells transform into cells with migration and invasion ability [23]. Thus, the negative inhibitory effect of ZONAB on E-cadherin expression suggests that up-regulation of ZONAB in bladder cancer enhances the invasive phenotype of bladder cancer. Epithelial-mesenchymal transition (EMT) is required for cell invasion involved in cancer progression $[24,25]$. To identify EMT following ZONAB up-regulation in bladder cancer, the expression of cytokeratin 8 as an epithelial marker and vimentin as a mesenchymal marker in xenograft tumor was detected by immunohistochemical staining. High expression rate of cytokeratin 8 was down-regulated and that of vimentin was up-regulated following $\mathrm{ZONAB}$ up-regulation $(\mathrm{p}<0.05$, Figure 8$)$. The findings above suggest that ZONAB up-regulation enhances EMT, which might be the important cause of invasion phenotype of bladder cancer cells.

\section{Discussion}

Cancer cell invasion is an important feature of malignant tumors. Cancer cells obtain mesenchymal phenotype and overcome the constraints of intercellular junctions between surrounding tissues to invade other tissues and survive. 

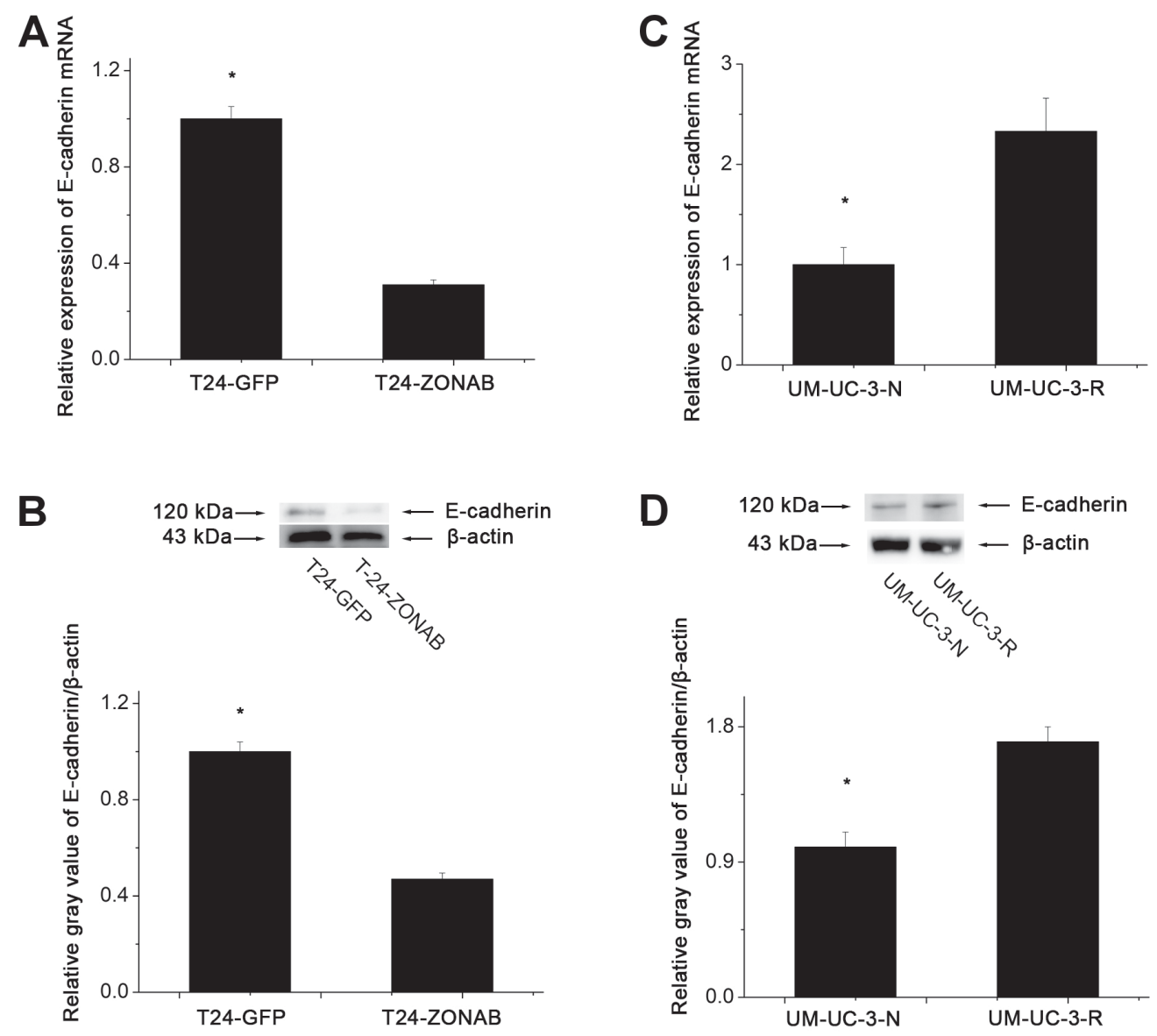

Figure 6. The expression of E-cadherin in bladder cancer cell lines was altered following ZONAB up-regulation or down-regulation. A) The expression of E-cadherin mRNA in negative control cell line T24-GFP and in ZONAB overexpressing cell line T24-ZONAB was detected by real-time PCR. Relative expression adjusted to the reference gene GAPDH and then standardized to T24-GFP is shown (mean \pm SD). ${ }^{*} \mathrm{p}<0.05$, Student's $\mathrm{t}$-test. B) The expression of E-cadherin protein in negative control cell line T24-GFP and in ZONAB overexpressing cell line T24-ZONAB was detected by Western blotting. Relative gray value adjusted to the internal control $\beta$-actin and then standardized to T24-GFP is shown (mean \pm SD). ${ }^{*} \mathbf{p}<0.05$, Student's $t$-test. C) The expression of E-cadherin mRNA in negative control cell line UM-UC-3-N and in ZONAB RNA interference cell line UM-UC-3-R was detected by real-time PCR. Relative expression adjusted to the reference gene GAPDH and then standardized to UM-UC-3-N is shown (mean \pm SD). ${ }^{*} \mathrm{p}<0.05$, Student's t-test. D) The expression of E-cadherin protein in negative control cell line UM-UC-3-N and in ZONAB RNA interference cell line UM-UC3-R was detected by Western blotting. Relative gray value adjusted to the internal control $\beta$-actin and then standardized to UM-UC-3-R is shown $($ mean $\pm \mathrm{SD}) .{ }^{*} \mathbf{p}<0.05$, Student's t-test.

Sometimes these invasive cells travel to distant sites via the circulatory system, which is called metastasis. The invasiveness and metastasis of malignant tumors are the major causes of death [26]. We found that ZONAB is overexpressed in bladder cancer cells. The invasive ability of bladder cancer cells is enhanced when ZONAB expression is up-regulated; whereas, the invasive ability is weakened when ZONAB expression is down-regulated. ZONAB expression enhances the invasive phenotype in bladder cancer. Our study results demonstrate that ZONAB expression is altered in the process of bladder cancer tumorigenesis and invasion. ZONAB is an important gene that regulates the invasive ability of bladder cancer cells.

Disorders in tight junction protein expression are common in malignancies and predict poor prognosis. The expression of claudin-1, claudin-4, and claudin-7 was significantly down-regulated in colorectal cancer cell membranes and showed significant ectopic intracytoplasmic expression [27]. Down-regulation of ZO-1 expression in hepatocellular carcinoma predicts lower postoperative recurrence-free and overall survival [28]. Decreased expression of claudin-6 in non-small cell lung cancer predicted a decrease in overall survival [29]. Studies have found that altered expression of tight junction protein is correlated with cancer cell biological behavior. For example, reconstruction of claudin-6 expression in cervical cancer cells can inhibit tumor growth and colony formation [30]. We demonstrate that ZONAB expression was elevated in both bladder cancer cells compared to control group, suggesting that ZONAB may be involved in tumorigenesis of bladder cancer. ZONAB expression is 

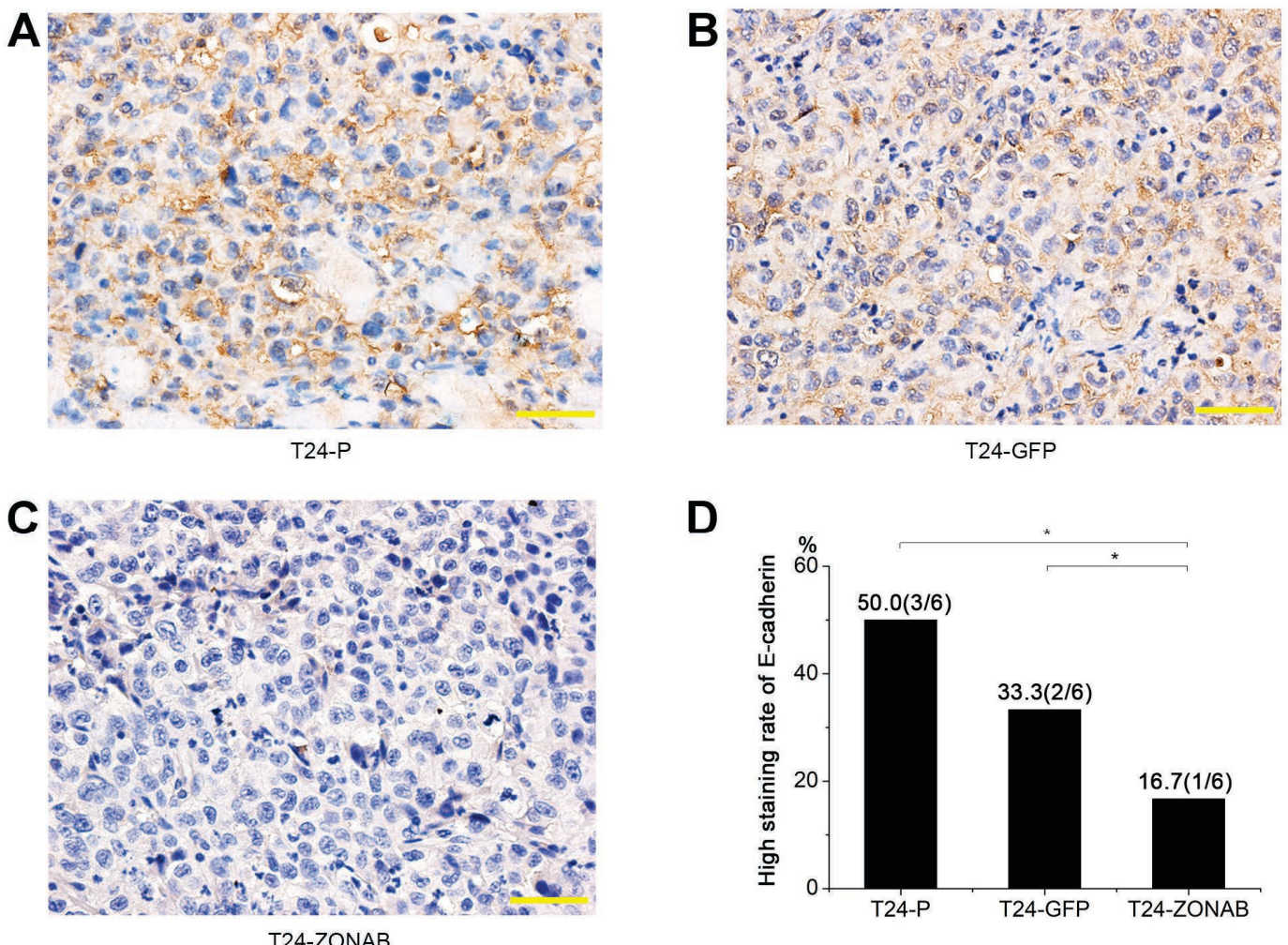

D

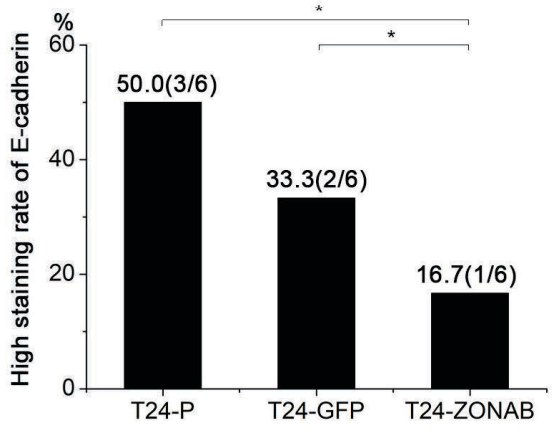

Figure 7. The expression of E-cadherin in xenograft tumor was down-regulated following ZONAB up-regulation. A) E-cadherin protein expression detected by immunohistochemical staining in xenograft tumor implanted with T24-P cells (original magnification $\times 400$. Scale bar, 50 $\mu$ m). B) Ecadherin protein expression detected by immunohistochemical staining in xenograft tumor implanted with T24-GFP cells (original magnification $\times 400$. Scale bar, $50 \mu \mathrm{m}$ ). C) E-cadherin protein expression detected by immunohistochemical staining in xenograft tumor implanted with T24-ZONAB cells (original magnification $\times 400$. Scale bar, $50 \mu \mathrm{m}$ ). D) The high staining rate of E-cadherin protein detected by immunohistochemical staining in xenograft tumors implanted with T24-P, T24-GFP and T24-ZONAB cells. ${ }^{*} \mathrm{p}<0.05$, Chi-square analysis.

altered because of an abnormal level of promoter methylation. Methylation of the promoter region is a major mechanism of ZONAB mRNA down-regulation in the acute myeloid leukemia cell line [31]. As we found, the up-regulation of ZONAB in bladder cancer can provide a novel target for the development of anti-tumor drugs in the future.

Dysregulation of tight junction proteins also plays an important role in tumor invasion. Promoter methylation leads to down-regulation of claudin-6 expression and promotion of cancer cell migration and invasion in breast cancer [32]. Nuclease-mediated occludin gene knock-down promotes invasion of breast cancer cells [17]. Down-regulation of claudin-7 and lipolysis-stimulated lipoprotein receptor (LSR) can promote invasion of endometrial cancer cells [33, 34]. In gastric cancer silencing of ZONAB increased expression of E-cadherin [15], which plays a critical role in inhibiting tumor cell invasion [16]. In order to further identify invasion-promoting functions of ZONAB, we manipulated the expression level of ZONAB in bladder cancer cells by stable transduction. We found that the invasive ability of bladder cancer cells increased when ZONAB expression was up-regulated. Animal experiments also showed that high expression of ZONAB promoted bladder cancer invasion into striated muscles. On the contrary, the invasive ability of bladder cancer cells decreased after down-regulation of ZONAB. Down-regulation of ZONAB in bladder cancer cells did not result in tumor formation at all in nude mice. These results suggest that ZONAB promotes tumor invasion in bladder cancer. Down-regulation of ZONAB leads to downregulation of TAK1, p38, JNK, and other MAPK signaling pathway members in colorectal cancer [35], while activation of MAPK signaling pathway plays an important role in the invasiveness of bladder cancer cells [36,37]. Our findings on the invasion-promoting role of ZONAB in bladder cancer provide a new target for development of intravesical instillation against tumor progression.

The HIF1 signaling pathway is activated to secrete cytokines and growth factors to promote angiogenesis, which is a key step in metastasis of bladder cancer [38, 39]. ZONAB represses the downstream promoter of HIF-1 via binding to the hypoxia-responsive region [40]. Our tumor xenograft study showed that up-regulation of ZONAB expression did 

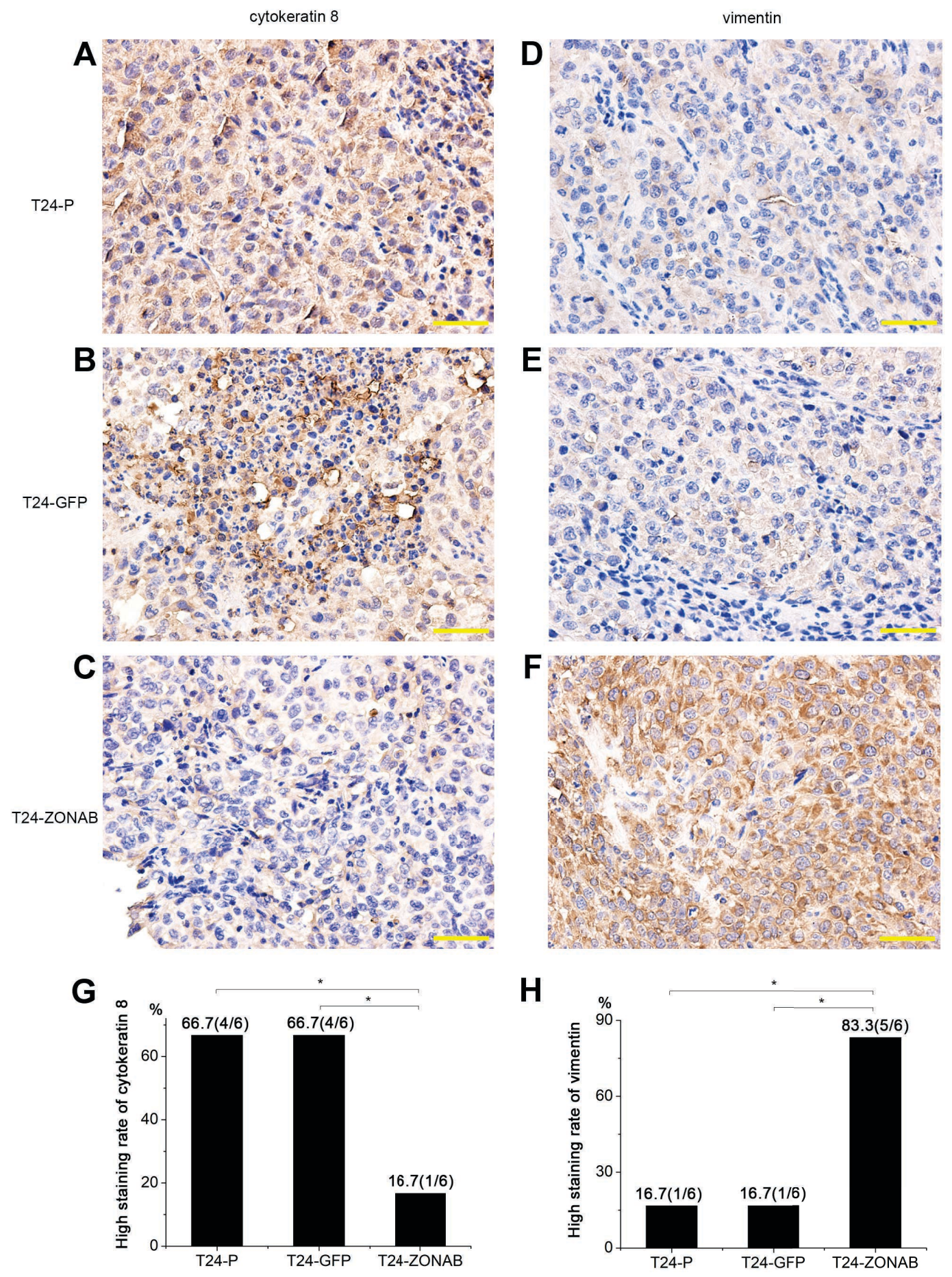

Figure 8. The expression of cytokeratin 8 and vimentin in xenograft tumor was altered following ZONAB up-regulation. A) Cytokeratin 8 protein expression detected by immunohistochemical staining in xenograft tumor implanted with T24-P cells (original magnification $\times 400$. Scale bar, $50 \mu \mathrm{m}$ ). B) Cytokeratin 8 protein expression detected by immunohistochemical staining in xenograft tumor implanted with T24-GFP cells (original magnification $\times 400$. Scale bar, $50 \mu \mathrm{m}$ ). C) Cytokeratin 8 protein expression detected by immunohistochemical staining in xenograft tumor implanted with T24ZONAB cells (original magnification $\times 400$. Scale bar, $50 \mu \mathrm{m}$ ). D) Vimentin protein expression detected by immunohistochemical staining in xenograft tumor implanted with T24-P cells (original magnification $\times 400$. Scale bar, $50 \mu \mathrm{m}$ ). E) Vimentin protein expression detected by immunohistochemical staining in xenograft tumor implanted with T24-GFP (original magnification $\times 400$. Scale bar, $50 \mu \mathrm{m}$ ). F) Vimentin protein expression detected by immunohistochemical staining in xenograft tumor implanted with T24-ZONAB (original magnification $\times 400$. Scale bar, $50 \mu \mathrm{m}$ ). G) The high staining rate of cytokeratin 8 protein detected by immunohistochemical staining in xenograft tumors implanted with T24-P, T24-GFP and T24-ZONAB cells. ${ }^{*} \mathrm{p}<0.05$, Chi-square analysis. H) The high staining rate of vimentin protein detected by immunohistochemical staining in xenograft tumors implanted with T24-P, T24-GFP and T24-ZONAB. ${ }^{*} \mathrm{p}<0.05$, Chi-square analysis. 
not enhance distant metastasis of bladder cancer. We speculate that the reason for these results may be that $\mathrm{ZONAB}$ promotes tumor invasion by disrupting cell adhesions and, at the same time, it might be involved in repression of the HIF1 signaling pathway to repress angiogenesis, resulting in repression of distant metastases.

The ZONAB gene is located on human chromosome 12 p13.2 and has a total length of $24 \mathrm{~kb}$ including 11 exons. It has double-stranded DNA binding activity, and transcription factor activity via binding to the GM-CSF promoter, as well as activity binding to intact mRNA or RNA fragments containing the 5'-UCCAUCA-3' sequence [41, 42]. When cell density is decreased, ZONAB is activated and translocated into the nucleus as a transcription factor [43]. ZONAB enters the nucleus to regulate proliferation, invasion, and metastasis in gastric cancer [12]. We found that the expression of E-cadherin was down-regulated in bladder cancer cells, which is consistent with results of Hussein and colleagues [44]. E-cadherin, which is an important component of adhesion junctions, plays an important role in EMT, invasion, and metastasis of bladder cancer cells [45-47]. We found a negative regulation of ZONAB on E-cadherin expression levels in bladder cancer. Similarly, E-cadherin expression is negatively regulated by ZONAB in gastric cancer [15]. Therefore, we speculate that ZONAB possesses an inhibitory function on E-cadherin expression in bladder cancer. On the other hand, decreased expression of E-cadherin enhanced the activity of ZONAB through regulation of tight junctions. E-cadherin can enhance formation, distribution, and integrity of tight junctions through the EGFR signaling pathway $[48,49]$. Decreased E-cadherin expression results in disruption of the tight junctions, and in activation and translocation of ZONAB into the nucleus of bladder cancer cells [11]. Therefore, as our results show, $\mathrm{ZONAB}$ activation has a role in promoting tumor invasion. Therefore, we hypothesize that ZONAB inhibits E-cadherin expression in bladder cancer cells and promotes invasion by disrupting both adhesion and tight junctions, which needs to be confirmed by further study.

Since epithelial-mesenchymal transition (EMT) is required for cell invasion involved in cancer progression $[24,25]$, we investigated the expression of EMT markers following ZONAB up-regulation and found that ZONAB can down-regulate the expression of cytokeratin 8 and up-regulate the expression of vimentin, which is consistent with the result of Jiménez-Salazar and his colleague's study in breast cancer [50]. Our findings demonstrate that ZONAB expression enhances epithelial-mesenchymal transition in bladder cancer. Further study is needed to identify whether down-regulation of E-cadherin is the essential step for the EMT-promoting role of ZONAB in bladder cancer.

In summary, the tight junction protein $\mathrm{ZONAB}$ is up-regulated in bladder cancer cells and can enhance the invasion, while down-regulation of ZONAB expression can inhibit the capacity of invasion in bladder cancer cells. Since
ZONAB expression is up-regulated throughout tumorigenesis of bladder cancer, this suggests that ZONAB may serve as a new target for the treatment and prevention of bladder cancer. Overall, our findings demonstrate that ZONAB has an important role in promoting bladder cancer invasion.

Acknowledgements: The present study was supported by a National Natural Science Foundation Youth Fund from National Natural Science Foundation of China (No. 81501292.). The authors would like to thank Mrs. Zhao Muli of China Medical University for her excellent technical assistance on cell culture and also thank Mrs. Gao Linlin of Shengjing Hospital for her kindly guidance on animal model preparation.

\section{References}

[1] MALATS N, REAL FX. Epidemiology of bladder cancer. Hematol Oncol Clin North Am 2015; 29: 177-189. https:/doi. org/10.1016/j.hoc.2014.10.001

[2] LOBO N, MOUNT C, OMAR K, NAIR R, THURAIRAJA R et al. Landmarks in the treatment of muscle-invasive bladder cancer. Nat Rev Urol 2017; 14: 565-574. https://doi. org/10.1038/nrurol.2017.82

[3] MCCONKEY DJ, LEE S, CHOI W, TRAN M, MAJEWSKI $\mathrm{T}$ et al. Molecular genetics of bladder cancer: Emerging mechanisms of tumor initiation and progression. Urol Oncol 2010; 28: 429-440. https://doi.org/10.1016/j. urolonc.2010.04.008

[4] YUN SJ, KIM WJ. Role of the epithelial-mesenchymal transition in bladder cancer: from prognosis to therapeutic target. Korean J Urol 2013; 54: 645-650. https://doi.org/10.4111/ kju.2013.54.10.645

[5] KAMAT AM, HAHN NM, EFSTATHIOU JA, LERNER SP, MALMSTROM PU et al. Bladder cancer. Lancet 2016; 388: 2796-2810. https://doi.org/10.1016/S0140-6736(16)30512-8

[6] KAMAT AM, COLOMBEL M, SUNDI D, LAMM D, BOEHLE A et al. BCG-unresponsive non-muscle-invasive bladder cancer: recommendations from the IBCG. Nat Rev Urol 2017; 14: 244-255. https://doi.org/10.1038/nrurol.2017.16

[7] MACLEOD LC, NGO TC, GONZALGO ML. Complications of intravesical bacillus calmette-guerin. Can Urol Assoc J 2014; 8: E540-544. https://doi.org/10.5489/cuaj.1411

[8] SUAREZ C, PUENTE J, GALLARDO E, MENDEZ-VIDAL MJ, CLIMENT MA et al. New advances in genitourinary cancer: evidence gathered in 2014. Cancer Metastasis Rev 2015; 34: 443-464. https://doi.org/10.1007/s10555-0159577-X

[9] MARTIN TA, JIANG WG. Loss of tight junction barrier function and its role in cancer metastasis. Biochim Biophys Acta 2009; 1788: 872-891. https://doi.org/10.1016/j. bbamem.2008.11.005

[10] RUAN YC, WANG Y, DA SILVA N, KIM B, DIAO RY et al. CFTR interacts with ZO-1 to regulate tight junction assembly and epithelial differentiation through the ZONAB pathway. J Cell Sci 2014; 127: 4396-4408. https://doi.org/10.1242/ jcs. 148098 
[11] SOURISSEAU T, GEORGIADIS A, TSAPARA A, ALI RR, PESTELL R et al. Regulation of PCNA and cyclin D1 expression and epithelial morphogenesis by the ZO-1-regulated transcription factor ZONAB/DbpA. Mol Cell Biol 2006; 26: 2387-2398. https://doi.org/10.1128/MCB.26.6.23872398.2006

[12] NA HK, LEE JY. Molecular Basis of Alcohol-Related Gastric and Colon Cancer. Int J Mol Sci 2017; 18. https://doi. org/10.3390/ijms18061116

[13] DUPASQUIER S, DELMARCELLE AS, MARBAIX E, COSYNS JP, COURTOY PJ et al. Validation of housekeeping gene and impact on normalized gene expression in clear cell renal cell carcinoma: critical reassessment of YBX3/ZONAB/ CSDA expression. BMC Mol Biol 2014; 15: 9. https://doi. org/10.1186/1471-2199-15-9

[14] LIMA WR, PARREIRA KS, DEVUYST O, CAPLANUSI A, N'KULI F et al. ZONAB promotes proliferation and represses differentiation of proximal tubule epithelial cells. J Am Soc Nephrol 2010; 21: 478-488. https://doi.org/10.1681/ ASN.2009070698

[15] WANG GR, ZHENG Y, CHE XM, WANG XY, ZHAO JH et al. Upregulation of human DNA binding protein A ( $\mathrm{dbpA})$ in gastric cancer cells. Acta Pharmacol Sin 2009; 30: 14361442. https://doi.org/10.1038/aps.2009.137

[16] WONG AS, GUMBINER BM. Adhesion-independent mechanism for suppression of tumor cell invasion by E-cadherin. J Cell Biol 2003; 161: 1191-1203. https://doi.org/10.1083/ jcb.200212033

[17] MARTIN TA, MANSEL RE, JIANG WG. Loss of occludin leads to the progression of human breast cancer. Int J Mol Med 2010; 26: 723-734. https://doi.org/10.3892/ ijmm_00000519

[18] CAO Q, WANG X, ZHAO M, YANG R, MALIK R et al. The central role of EED in the orchestration of polycomb group complexes. Nat Commun 2014; 5: 3127. https://doi. org/10.1038/ncomms4127

[19] MERVE A, DUBUC AM, ZHANG X, REMKE M, BAXTER $\mathrm{PA}$ et al. Polycomb group gene BMI1 controls invasion of medulloblastoma cells and inhibits BMP-regulated cell adhesion. Acta Neuropathol Commun 2014; 2: 10. https://doi. org/10.1186/2051-5960-2-10

[20] YI X, GUO J, GUO J, SUN S, YANG P et al. EZH2-mediated epigenetic silencing of TIMP2 promotes ovarian cancer migration and invasion. Sci Rep 2017; 7: 3568. https://doi. org/10.1038/s41598-017-03362-Z

[21] MATOS ML, LAPYCKYJ L, ROSSO M, BESSO MJ, MENCUCCI MV et al. Identification of a Novel Human E-Cadherin Splice Variant and Assessment of Its Effects Upon EMT-Related Events. J Cell Physiol 2017; 232: 1368-1386. https://doi.org/10.1002/jcp.25622

[22] REN Y, WU Q, LIU Y, XU X, QUAN C. Gene silencing of claudin6 enhances cell proliferation and migration accompanied with increased MMP2 activity via p38 MAPK signaling pathway in human breast epithelium cell line HBL100. Mol Med Rep 2013; 8: 1505-1510. https://doi.org/10.3892/ mmr.2013.1675
[23] DERKSEN PW, LIU X, SARIDIN F, VAN DER GULDEN $\mathrm{H}$, ZEVENHOVEN J et al. Somatic inactivation of E-cadherin and p53 in mice leads to metastatic lobular mammary carcinoma through induction of anoikis resistance and angiogenesis. Cancer Cell 2006; 10: 437-449. https://doi. org/10.1016/j.ccr.2006.09.013

[24] XIE Y, JIN P, SUN X, JIAO T, ZHANG Y et al. SIX1 is upregulated in gastric cancer and regulates proliferation and invasion by targeting the ERK pathway and promoting epithelialmesenchymal transition. Cell Biochem Funct 2018. https:// doi.org/10.1002/cbf.3361

[25] MA L, YU Y, QU X. Suppressing serum response factor inhibits invasion in cervical cancer cell lines via regulating Egr1 and epithelial-mesenchymal transition. Int J Mol Med 2019; 43: 614-620. https://doi.org/10.3892/ijmm.2018.3954

[26] XU Q, DENG F, QIN Y, ZHAO Z, WU Z et al. Long noncoding RNA regulation of epithelial-mesenchymal transition in cancer metastasis. Cell Death Dis 2016; 7: e2254. https:// doi.org/10.1038/cddis.2016.149

[27] HAHN-STROMBERG V, ASKARI S, AHMAD A, BEFEKADU R, NILSSON TK. Expression of claudin 1, claudin 4, and claudin 7 in colorectal cancer and its relation with CLDN DNA methylation patterns. Tumour Biol 2017; 39: 1010428317697569. https://doi. org/10.1177/1010428317697569

[28] NAGAI T, ARAO T, NISHIO K, MATSUMOTO K, HAGIWARA $S$ et al. Impact of Tight Junction Protein ZO-1 and TWIST Expression on Postoperative Survival of Patients with Hepatocellular Carcinoma. Dig Dis 2016; 34: 702-707. https://doi.org/10.1159/000448860

[29] WANG Q, ZHANG Y, ZHANG T, HAN ZG, SHAN L. Low claudin-6 expression correlates with poor prognosis in patients with non-small cell lung cancer. Onco Targets Ther 2015; 8: 1971-1977. https://doi.org/10.2147/OTT.S85478

[30] ZHANG X, RUAN Y, LI Y, LIN D, QUAN C. Tight junction protein claudin- 6 inhibits growth and induces the apoptosis of cervical carcinoma cells in vitro and in vivo. Med Oncol 2015; 32: 148. https://doi.org/10.1007/s12032-015-0600-4

[31] WONG JJ, LAU KA, PINELLO N, RASKO JE. Epigenetic modifications of splicing factor genes in myelodysplastic syndromes and acute myeloid leukemia. Cancer Sci 2014; 105: 1457-1463. https://doi.org/10.1111/cas.12532

[32] LIU Y, JIN X, LI Y, RUAN Y, LU Y et al. DNA methylation of claudin- 6 promotes breast cancer cell migration and invasion by recruiting $\mathrm{MeCP} 2$ and deacetylating $\mathrm{H} 3 \mathrm{Ac}$ and H4Ac. J Exp Clin Cancer Res 2016; 35: 120. https://doi.org/10.1186/ s13046-016-0396-X

[33] LI X, LI Y, QIU H, WANG Y. Downregulation of claudin-7 potentiates cellular proliferation and invasion in endometrial cancer. Oncol Lett 2013; 6: 101-105. https://doi.org/10.3892/ ol.2013.1330

[34] SHIMADA H, ABE S, KOHNO T, SATOHISA S, KONNO T et al. Loss of tricellular tight junction protein LSR promotes cell invasion and migration via upregulation of TEAD1/ AREG in human endometrial cancer. Sci Rep 2017; 7: 37049. https://doi.org/10.1038/srep37049 
[35] LIU R, WANG G, LIU C, QIU J, YAN L et al. Gene expression profile analysis of $\mathrm{dbpA}$ knockdown in colorectal cancer cells. Cell Biol Int 2016; 40: 1280-1293. https://doi. org/10.1002/cbin.10670

[36] DANGLE PP, ZAHARIEVA B, JIA H, POHAR KS. RasMAPK pathway as a therapeutic target in cancer - emphasis on bladder cancer. Recent Pat Anticancer Drug Discov 2009; 4: 125-136. https://doi.org/10.2174/157489209788452812

[37] KUMAR B, KOUL S, PETERSEN J, KHANDRIKA L, HWA JS et al. p38 mitogen-activated protein kinase-driven MAPKAPK2 regulates invasion of bladder cancer by modulation of MMP-2 and MMP-9 activity. Cancer Res 2010; 70: 832841. https://doi.org/10.1158/0008-5472.CAN-09-2918

[38] THEODOROPOULOS VE, LAZARIS A, SOFRAS F, GERZELIS I, TSOUKALA V et al. Hypoxia-inducible factor 1 alpha expression correlates with angiogenesis and unfavorable prognosis in bladder cancer. Eur Urol 2004; 46: 200-208. https://doi.org/10.1016/j.eururo.2004.04.008

[39] CHEN MC, HSU WL, HWANG PA, CHOU TC. Low Molecular Weight Fucoidan Inhibits Tumor Angiogenesis through Downregulation of HIF-1/VEGF Signaling under Hypoxia. Mar Drugs 2015; 13: 4436-4451. https://doi.org/10.3390/ md13074436

[40] COLES LS, DIAMOND P, LAMBRUSCO L, HUNTER J, BURROWS J et al. A novel mechanism of repression of the vascular endothelial growth factor promoter, by single strand DNA binding cold shock domain (Y-box) proteins in normoxic fibroblasts. Nucleic Acids Res 2002; 30: 48454854.

[41] COLES LS, DIAMOND P, OCCHIODORO F, VADAS MA, SHANNON MF. Cold shock domain proteins repress transcription from the GM-CSF promoter. Nucleic Acids Res 1996; 24: 2311-2317.

[42] PETRUZZELLI R, GAUDINO S, AMENDOLA G, SESSA R, PUZONE $S$ et al. Role of the cold shock domain protein $A$ in the transcriptional regulation of HBG expression. Br J Haematol 2010; 150: 689-699. https://doi.org/10.1111/j.13652141.2010.08303.X
[43] FRANKEL P, ARONHEIM A, KAVANAGH E, BALDA MS, MATTER K et al. RalA interacts with ZONAB in a cell density-dependent manner and regulates its transcriptional activity. EMBO J 2005; 24: 54-62. https://doi.org/10.1038/ sj.emboj.7600497

[44] HUSSEIN S, MOSAAD H, RASHED HE, AHMED S, RA$\mathrm{GAB}$ et al. Molecular factors regulating E-cadherin expression in urothelial bladder cancer and their correlations with the clinicopathological features. Mol Biol Rep 2017; 44: 365377. https://doi.org/10.1007/s11033-017-4118-Z

[45] ZHAO J, DONG D, SUN L, ZHANG G, SUN L. Prognostic significance of the epithelial-to-mesenchymal transition markers e-cadherin, vimentin and twist in bladder cancer. Int Braz J Urol 2014; 40: 179-189. https://doi.org/10.1590/ S1677-5538.IBJU.2014.02.07

[46] MAO Q, LI Y, ZHENG X, YANG K, SHEN H et al. Up-regulation of E-cadherin by small activating RNA inhibits cell invasion and migration in 5637 human bladder cancer cells. Biochem Biophys Res Commun 2008; 375: 566-570. https:// doi.org/10.1016/j.bbrc.2008.08.059

[47] IMAO T, KOSHIDA K, ENDO Y, UCHIBAYASHI T, SASAKI $\mathrm{T}$ et al. Dominant role of E-cadherin in the progression of bladder cancer. J Urol 1999; 161: 692-698. https://doi. org/10.1016/S0022-5347(01)61997-9

[48] RUBSAM M, MERTZ AF, KUBO A, MARG S, JUNGST C et al. E-cadherin integrates mechanotransduction and EGFR signaling to control junctional tissue polarization and tight junction positioning. Nat Commun 2017; 8: 1250. https:// doi.org/10.1038/s41467-017-01170-7

[49] TRAN QT, KENNEDY LH, LEON CARRION S, BODREDDIGARI S, GOODWIN SB et al. EGFR regulation of epidermal barrier function. Physiol Genomics 2012; 44: 455-469. https://doi.org/10.1152/physiolgenomics.00176.2011

[50] JIMENEZ-SALAZAR JE, POSADAS-RODRIGUEZ P, LAZZARINI-LECHUGA RC, LUNA-LOPEZ A, ZENTELLADEHESA A et al. Membrane-initiated estradiol signaling of epithelial-mesenchymal transition-associated mechanisms through regulation of tight junctions in human breast cancer cells. Horm Cancer 2014; 5: 161-173. https://doi. org/10.1007/s12672-014-0180-3 